\title{
MANAJEMEN KOMUNIKASI DALAM PELAYANAN KETERBUKAAN INFORMASI PUBLIK KEPADA MASYARAKAT DI PEJABAT PENGELOLA INFORMASI DAN DOKUMENTASI (PPID) KABUPATEN TUBAN
}

\author{
Nibrosu Rohid', Redi Panuju² \\ Universitas Dr. Soetomo
}

Email: nibrosurohid@yahoo.co.id'1, Redi.panuju@unitomo.ac.id²

\begin{abstract}
Abstrak
Manajemen komunikasi merupakan proses pengelolaan sumber daya dalam suatu organisasi atau instusi. Dalam penelitian ini, didasar pada minimnya masyarakat yang menggunakan haknya dalam suatu lembaga Pejabat Pengelola Informasi dan Dokumentasi (PPID) Kabupaten Tuban. Oleh karena itu, penelitian ini difokuskan pada manajemen komunikasi pelayanan keterbukaan infromasi publik. Sehingga dalam tujuan penelitian ini adalah untuk mengetahui seluruh proses pengelolaan yang ada dalam PPID Kabupaten Tuban, mulai dari tugas, fungsi sampai pada maslah yang dihadapi dalam pelaksanaan pelayanan. penelitian ini menggunakan metode diskriptif kualitatif dengan cara audit komunikasi internal PPID Kabupaten Tuban. Metode manajemen komunikasi dalam penelitian ini meliputi Perencanaan, Pengorganisasian, Pengoordinasian, Pengomunikasian, Pelaksanaan, Pengawasan, Pengevaluasian, Pemodifikasian dengan menggunakan Teori sistem sosial. Berdasarkan hasil penelitian, pada dasarnya PPID Kabupaten Tuban sudah melaksanakan Manajemen Komunikasi, namun dalam pelaksanaanya kurang maksimal dan masih ada kendala dari internal maupun eksternal. Kendala-kendala itu diantaranya adalah kurang maskimalnya kinerja dari PPID Pembantu yang disebabkan karena kurangnya koordinasi dengan PPID Tuban, kurang maksimalnya sosialisasi keberadaan PPID. Sehingga ini berakibat pada minimnya masyarakat yang menggunakan haknya karena ketidak tahuan keberadaan PPID Tuban dan menjadikan kendala bagi pelaksanaan pelayanan keterbukaan informasi publik di Kabupaten Tuban.
\end{abstract}

Kata Kunci: Manajemen Komunikasi, Informasi Publik, Pelayanan Publik 


\section{PENDAHULUAN}

Berkomunikasi merupakan keharusan bagi manusia, karena dengan komunikasi beberapa kebutuhan manusia akan terpenuhi, baik kebutuhan pokok maupun kebutuhan informasi. Kebutuhan akan informasi pada saat ini sangatlah penting, karena setiap manusia dituntut untuk selalu mengikuti perkembangan zaman. Kebutuhan informasi masyarakat saat ini sudah tidak bisa dicegah karena sekarang Indonesia memang memasuki era keterbukaan informasi, hal ini ditunjang dengan adanya UU Nomor 14 tahun 2008 tentang Keterbukaan Informasi Publik (KIP). Dalam konteks masyarakat yang lebih luas, konsep transparansi informasi ini belum dipahami dengan baik. Konsekuensinya keberadaan UU keterbukaan informasi ini kurang populer dan implementasinya jauh dari harapan. Padahal banyak pihak berharap hadirnya regulasi ini mampu mendorong iklim keterbukaan yang luas di berbagai badan publik.

Kebutuhan informasi yang dibutuhkan masyarakat biasanya bisa diakses melalui media massa, akan tetapi ada juga yang tidak bisa diakses melalui media massa. Sehingga masyarakat dituntut untuk mencari informasi dengan berkunjung ke pusat informasi, pusat informasi disini yang dimaksudkan adalah kantor instansi yang bersangkutan. Dalam pelaksanaan keterbukaan informasi tersebut biasanya jika memang bersentuhan secara langsung dengan instansi, maka akan berhubungan dengan yang namanya pelayanan.

Pelayanan merupakan suatu kegiatan yang diselenggarakan oleh orang atau lembaga untuk menyediakan kebutuhan barang atau jasa kepada masyarakat. Pelayanan dalam suatu instansi pemerintahan sangat sering dikeluhkan oleh masyarakat, hal ini dikarenakan oleh sistem pelayanan yang membuat bingung masyarakat atau individuindividu yang ada dalam instansi terkait. Suatu sistem pelayanan yang tidak layak atau bisa membuat masyarakat bingung maka akan berdampak negatif pada instansi tersebut. Begitu juga individu yang ada di dalam instansi jika memang tidak bisa melayani dengan baik, maka akan berdampak negatif juga pada instansi terkait. Sehingga dalam suatu pelayanan dibutuhkan prosedural yang efektif dan individu yang kredibel untuk membuat citra positif 
bagi suatu instansi. Penyelenggaraan pelayanan pemerintah atau biasa disebut dengan pelayanan publik merupakan upaya negara untuk memenuhi kebutuhan dasar dan hak-hak sipil setiap warga negara atas barang dan jasa yang disediakan oleh penyelenggara pelayanan publik. Disamping pelayanan tersebut juga didampingi dengan yang namanya keterbukaan atau transparansi informasi. Transparansi informasi menjadi ciri khas negara yang baik dalam pelaksanaan tata kelolanya.

Suatu pelayanan yang terbaik juga tidak bisa lepas dengan yang namanya proses komunikasi yang terjadi di dalamnya. Proses komunikasi yang terjadi dalam suatu pelayanan haruslah berjalan efektif, supaya pelayanan juga bisa efektif dan dapat memuaskan masyarakat yang minta pelayanan. Disamping itu juga, petugas atau individu dalam juga harus kredibel, karena petugas pemberi layanan adalah orang yang secara personal yang akan melayani publik. Sehingga petugas pemberi layanan harus mengetahui bagaimana berkomunikasi yang baik sehingga mampu mempengaruhi orang lain khususnya dalam pelayanan.

Konteks komunikasi kebijakan keterbukaan informasi adalah bagaimana metode manajemen komunikasi yang dilakukan pemerintah untuk mereduksi resistensi penerapan keterbukaan informasi badan publik. Masalah lain yang juga penting yaitu penyamaan persepsi mengenai keterbukaan informasi yang multi tafsir agar meminimalisir sengketa baik antar badan publik maupun antara badan publik dengan masyarakat. Manajemen komunikasi pemerintah diarahkan dua target sasaran publik yaitu internal dan eksternal. Kepada internal bertujuan menggugah kesadaran akan pentingnya transparansi melalui keberadaan UU KIP, komitmen implementasi dan akuntabilitas pemerintah. Pada target publik eksternal memiliki tujuan antara lain melakukan edukasi, inisiasi partisipasi dan pemberdayaan masyarakat mengenai hak konstitusional akan informasi sebagai perwujudan negara demokrasi. Keberhasilan kegiatan komunikasi banyak ditentukan oleh manajemen komunikasi yang diterapkan. Di lain pihak jika tidak ada manajemen komunikasi 
yang baik, efek dari proses komunikasi (terutama komunikasi media massa) bukan tidak mungkin akan menimbulkan pengaruh negatif.

Nickels, McHug and McHug menerangkan bahwa manajemen dalam suatu organisasi mempunyai fungsi sebagai Perencanaan, organisir, pelaksanaan dan kontrol atau biasa disebut dengan POAC (Planning, Organizing, Actuating, Controlling). Sehingga dalam melaksanakan tugasnya, fungsi tersebut juga digunakan untuk memajukan dan mengelola organisasi PPID. (Mukarom:2015). Konsep dasar manajemen tersebut, kemudian dikembangkan oleh Desseler (1996) dalam tahap-tahap manajemen komunikasi dalam sebuah organisasi yang meliputi Perencanaan (Planning), Pengorganisasian (organizing), Pengoordinasian (Coordinating), Pengomunikasian (Comunication), Pelaksanaan (Actuating), Pengawasan (Controlling), Pengevaluasian (Evaluating), Pemodifikasian (Modificating).

Indonesia dalam pelaksanaan pelayanan publik khususnya dibidang keterbukaan informasi, maka setiap daerah kabupaten yang ada di Indonesia membuat suatu lembaga Pejabat Pengelola Informasi dan Dokumentasi (PPID) untuk mempermudah pelayanan publik kepada masyarakat. Berdasarkan Peraturan Komisi Informasi Nomor 1 Tahun 2010 tentang Standar Layanan Informasi Publik, Pejabat Pengelola Informasi dan Dokumentasi (PPID) bertanggungjawab di bidang layanan informasi publik yang meliputi proses penyimpanan, pendokumentasian, penyediaan dan pelayanan informasi publik. PPID juga bertanggungjawab mengkoordinasikan penyimpanan dan pendokumentasian seluruh informasi publik yang berada di Badan Publik.

Sebagai bagian dari wilayah Indonesia, Kabupaten Tuban juga mempunyai lembaga PPID yang bertanggung jawab untuk mengelola seluruh informasi dan dokumentasi yang ada di Kabupaten Tuban. PPID Kabupaten Tuban dalam melaksanakan tugasnya dibantu oleh PPID Pembantu sebagai anggota yang ada di instansi-instansi pemerintah dibawah naungan Pemerintah Kabupaten Tuban, seperti di dinas-dinas Kabupaten Tuban, Rumah Sakit milik Pemerintah Daerah Tuban, Puskesmas-puskesmas di desa-desa. PPID dan PPID 
Pembantu yang ada di Kabupaten Tuban ini dibentuk berdasakan SK Bupati Nomor 188.45/122/KPTS/414.012/2012 tentang pejabat pengelola informasi dan dokumentasi kabupaten Tuban.

Berdasarkan data yang ada di www.ppid.tubankab.go.id dalam proses pelayanan dan keterbukaan publik ini, masih banyak pemohon informasi yang kemudian tidak bisa mendapatkan informasi publik yang diinginkannya. Hal ini bisa dibuktikan dengan jumlah pemohon yang tidak bisa mendapatkan informasi sebanyak 20,5\% dari total $100 \%$ pemohon. Dengan jumlah prosentase yang lebih dari seperempat itu, maka bisa dikatakan cukup banyak. Pemohon yang tidak bisa mendapatkan informasi ini bisa digolongkan dalam tiga bagian, ada yang tidak diberikan, ada yang ditolak dan ada yang keberatan.

Permohonan yang tidak dikabulkan akan membuat masyarakat cenderung malas untuk bersentuhan dengan pemerintah, apalagi dalam hal pelayanan keterbukaan informasi yang dirasa tidak memuaskan, sehingga membuat masyarakat malas untuk meminta pelayanan dari pemerintah. Pemohon Informasi yang pernah melakukan permintaan informasi publik namun di tolak oleh PPID dengan alasan bahwa permohonannya tidak sesuai prosedural. Hal ini membuat masyarakat semakin malas untuk meminta pelayanan dari pemerintah.

Beberapa uraian di atas menunjukkan bahwa manajemen komunikasi mempunyai peranan penting dalam sebuah pelayanan, hal ini dikarena komunikasi merupakan aspek yang sangat menetukan bagi pelaksanaan pelayanan publik. Sehingga manajemen komunikasi dalam sebuah pelayanan sangat diperlukan dan memegang peranan penting di dalam kesuksesan pelayanan. Khususnya pada suatu lembaga yang bertanggungjawab dalam keterbukaan informasi publik yaitu Pejabat Pengelola Informasi dan Dokumentasi (PPID).

Tujuan dalam penulisan jurnal ini adalah untuk mengetahui Mengetahui tugas, fungsi, dan peran Pejabat Pengelola Informasi dan Dokumentasi (PPID) Tuban dalam mengidentifikasi permasalahan terkait komunikasi kebijakan transparansi informasi baik 
organisasional maupun publik, Memperoleh gambaran mengenai program, perencanaan serta kendala yang adan dalam manajemen komunikasi PPID, Mendapatkan referensi aplikasi praktis terkait implementasi dan komunikasi kebijakan transparansi informasi publik, dan Mengetahui proses manajemen komunikasi PPID Tuban dalam Pelayanan Keterbukaan Informasi Publik Kepada Masyarakat Di Kabupaten Tuban.

\section{METODE PENELITIAN}

Penelitian ini hanya dilakukan terhadap menejemen komunikasi dalam pelayanan keterbukaan informasi yang dilaksanakan oleh Pejabat pengelola Informasi dan Dokumentasi (PPID) Kabupaten Tuban. Dalam keterbukaan informasi ini merupakan tanggung jawab dari pada Pejabat pengelola Informasi dan Dokumentasi (PPID). Sehingga dalam pelaksanana pelayanan keterbukaan Informasi ini perlu kita ketahui terkait proses menejemen komunikasi yang ada untuk mengetahui dan menguji kelayakan konsepsi manajemen yang sudah ditetapkan.

Penelitian ini mempunyai konsep penelitian Menejemen Komunikasi dalam Pelayanan Keterbukaan Informasi Publik Di Pejabat Pengelola Informasi dan Dokumentasi (PPID) Kabupaten Tuban. Penelitian ini menggunakan metode penulisan diskriptif kualitatif dengan metode audit komunikasi mini yang bertujuan untuk mengetahui proses manajemen komunikasi dalam pelaksanaan pelayanan yang ada di instasi PPID Kabupaten Tuban.

Teori dalam penelitian ini adalah Sistem Sosial. Menurut Owens bahwa teori sistem mempunyai dua konsep dasar yaitu yang pertama adalah konsep subsistem yang melihat hubungan antar bagian sebagai hubungan sebab akibat. Konsep kedua adalah hubungan yang saling berkaitan, maksudnya adalah tiap bagian merupakan kumpulan yang tiap subnya mempunyai keterkaitan.

Penelitian ini menggunakan metode pengumpulan data Wawancara dengan informannya adalah Ketua PPID Kabupaten Tuban, observasi di tempat pelayanan PPID 
Tuban dan dokumentasi. Sehingga jenis sumber datanyapun dibagi menjadi dua yaitu yang pertama data primer merupakan sumber data yang akan digunakan dalam penelitian yang diambil dan didapatkan dari subjek penelitian. Dalam penelitian ini, sumber data primernya adalah Observasi dan Wawancara. Sedangkan yang kedua adalah data sekunder merupakan sumber data yang akan digunakan dalam penelitian yang diambil dan dikumpulkan dari pihak-pihak lain yang berkaitan dan atau berkewenangan. Dalam penelitian ini, sumber datas adalah dokumentasi.

Analisis dalam penelitian ini mempunyai empat komponen utama yaitu pengumpulan data, reduksi data, penyajian data dan menarik kesimpulan. (Sugiyono, 2014:99)

\section{DISKUSI DAN ANALISIS}

Pejabat Pengelola Informasi dan Dokumentasi (PPID) Kabupaten Tuban merupakan Lembaga yang berada dibawah naungan Dinas Komunikasi dan Informatika (Diskominfo) Kabupaten Tuban. PPID Kabupaten Tuban bertanggungjawab di bidang layanan informasi publik yang meliputi proses penyimpanan, pendokumentasian, penyediaan dan pelayanan informasi publik. PPID juga bertanggungjawab mengkoordinasikan penyimpanan dan pendokumentasian seluruh informasi publik yang berada di Badan Publik Berdasarkan Peraturan Komisi Informasi Nomor 1 Tahun 2010 tentang Standar Layanan Informasi Publik. Pemberlakukan Undang-Undang Nomor 14 Tahun 2008 tentang Keterbukaan Informasi Publik (UU KIP) merupakan pintu gerbang menuju sistem kepemerintahan yang baik (good governance), khususnya di Kabupaten Tuban. UU KIP menjamin hak masyarakat untuk mengakses informasi yang mana setiap Badan Publik mempunyai kewajiban dalam menyediakan dan melayani permohonan informasi publik sesuai tata cara yang telah ditentukan. Dengan demikian, masyarakat dapat memantau aktivitas badan publik dan diharapkan dapat mendorong transparansi badan publik. (Sumber: Dokumen PPID) 
Berdasarkan Peraturan Komisi Informasi Nomor 1 Tahun 2010 tentang Standar Layanan Informasi Publik, Pejabat Pengelola Informasi dan Dokumentasi (PPID) bertanggungjawab di bidang layanan informasi publik yang meliputi proses penyimpanan, pendokumentasian, penyediaan dan pelayanan informasi publik. PPID juga bertanggungjawab mengkoordinasikan penyimpanan dan pendokumentasian seluruh informasi publik yang berada di Badan Publik. Oleh karena itu, untuk menunjang dan mempermudah tugas PPID, Pemerintah Kabupaten Tuban menyediakan website ppid.tubankab.go.id dan sarana prasarana yang dikelola oleh Bagian Humas dan Media. (Sumber: Dokumen PPID)

Kantor Alamat Pejabat Pengelola Informasi dan Dokumentasi (PPID) Kabupaten Tuban berada di Jalan Kartini Nomor 2 Kecamatan Tuban Kabupaten Tuban atau di lingkungan Kantor Pemerintah Daerah Kabupaten Tuban. Adapun struktural dalam PPID Tuban adalah sebagai berikut:

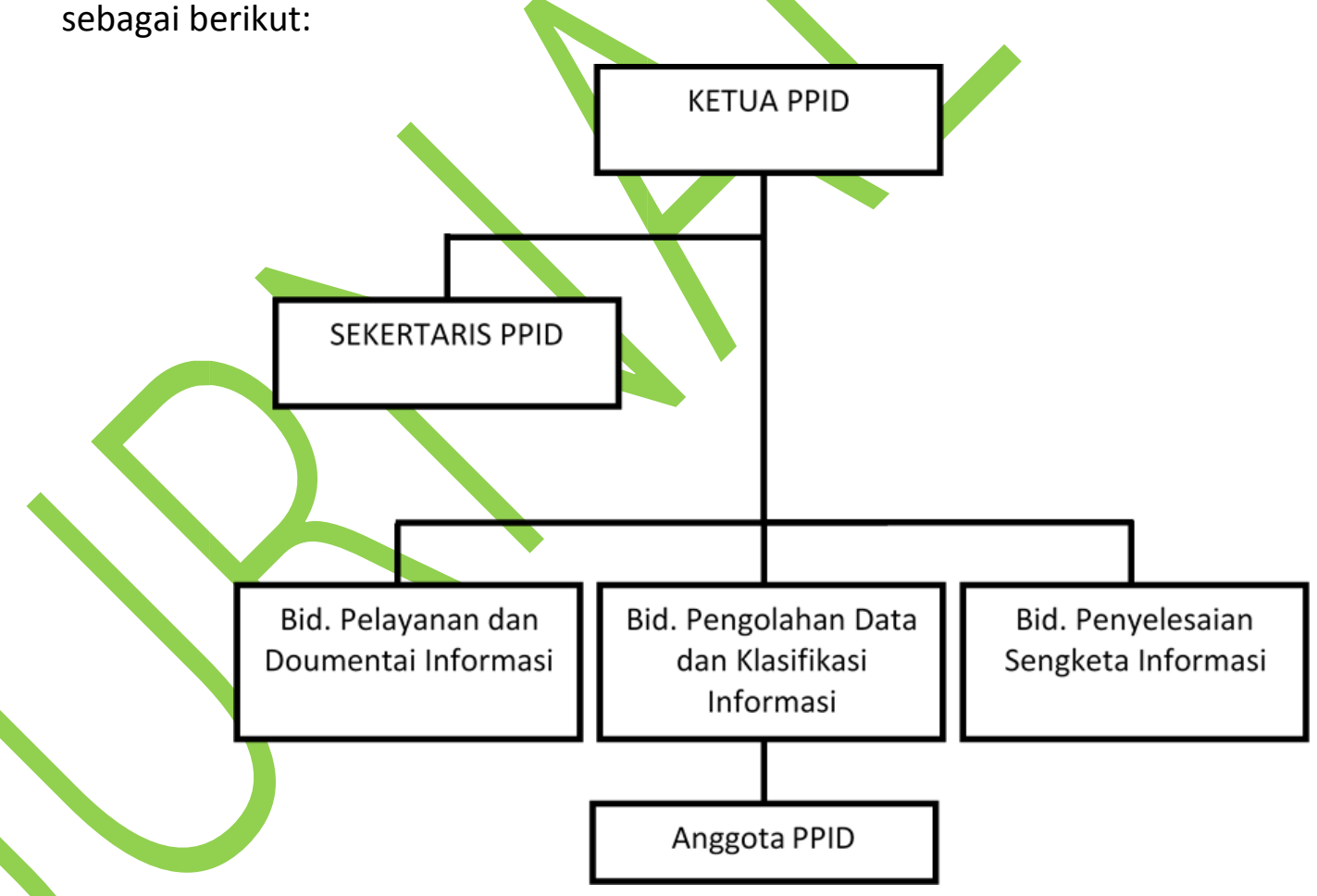

\section{Gambar 1. Struktur PPID Kabupaten Tuban}

Sumber: Dokumen PPID Tuban 
Pelaksanaan pelayanan keterbukaan informasi publik ini, pemerintah kabupaten Tuban tidak bisa lepas dengan yang namanya manajemen komunikasi. Manajemen komunikasi dalam hal ini meliputi perencanaan, pengorganisasian, pengkoordinasian, pengkomunikasian, pelaksanaan, pengawasan, pemodifikasian. Pelaksanaan penelitian yang sudah dilaksanakan pada bulan Juni 2017 tentang menejemen komunikasi pejabat pengelola informasi dan dokumentasi di Kabupaten Tuban menghasilkan temuan yang disesuaikan dengan jenis sumber data yaitu data skunder dan data primer. Data-data yang ditemukan kemudian direduksi sesuai dengan manajemen komunikasi yang meliputi perencanaan, pengorganisasian, pengkoordinasian, pengkomunikasian, pelaksanaan, pengawasan, pemodifikasian. Dalam menganalisis data ini disesuaikan dengan pendapat Bogdan \& Biklen (Sugiyono, 2014:99) Manajemen komunikasi yang dilakukan oleh Pejabat Pengelola Informasi dan Dokumentasi (PPID) Kabupaten Tuban dalam hal perencanaannya berdasarkan data memang sudah sesuai dengan peraturan yang berlaku, mulai dari pembentukan struktur sampai pada pembentukan Standart Operasional Prosedural (SOP). Seperti dalam pelaksanaan pelayanan keterbukaan informasi publik, PPID Kabupaten Tuban menggunakan dasar UU Nomor 25 Tahun 2009 tentang Pelayanan Publik, Peraturan Komisi Informasi Nomor 1 Tahun 2010 tentang Standar Layanan Informasi Publik dan peraturan bupati Tuban nomor 59 tahun 2015 tentang Penetapan Standar Operasional Prosedur Pelayanan Informasi Publik Pejabat Pengelola Informasi dan Dokumentasi di Lingkungan Pemerintah Kabupaten Tuban. Sehingga dalam melaksanakan tugasnya, para pejabat tidak bisa lepas dengan yang namanya peraturan ini.

Pejabat Pengelola Informasi dan Dokumentasi (PPID) Kabupaten Tuban untuk menjaga kualitas dalam pelayanannya, juga mempunyai standart waktu dalam pelayanan. Adapun waktu yang sudah ditentukan oleh PPID adalah 7 (Tujuh) hari jam kerja. Jadi, jika ada pemohon yang meminta informasi ataupun dokumen kepada PPIDTuban, maka dia bisa menerima dengan waktu maksimal 7 hari tersebut. Jikalau dalam waktu tersebut 
PPIDTuban belum bisa memenuhi keinginan pemohon, maka PPID Tuban akan meminta waktu lagi kepada pemohon untuk diberikan waktu 10 (Sepuluh) hari jam kerja.

Perencanaan yang sedemikian sudah disusun mulai tahun 2009 dan dilaksanakan pada tahun 2010 dan pada tahun 2012 terjadi restrukturisasi Pejabat Pengelola Informasi dan Dokumentasi berdasarkan SK Bupati Tuban Nomor 188.45/122/KPTS/414.012/2012 tentang Pejabat Pengelola Informasi dan Dokumentasi Kabupaten Tuban. Kemudian dalam hal pengorganisasian Pejabat Pengelola Informasi dan Dokumentasi (PPID) Kabupaten Tuban, para pejabat ditunjuk langsung oleh Bupati Tuban yang berdasarkan Surat Keputusan Bupati Tuban Nomor 188.45/122/KPTS/414.012/2012 tentang Pejabat Pengelola Informasi dan Dokumentasi Kabupaten Tuban.

Penempatan pejabat PPID Kabupaten Tuban ini melibatkan Organisasi Perangkat Daerah (OPD) kabupaten Tuban yang disesuaikan dengan bidang dalam internal PPID. Seperti dalam bidang penanganan sengketa, maka yang diposisikan adalah OPD bidang Hukum Pemerintah Daerah. Sehingga dalam penempatan tersebut sudah sesuai dengan kompetensi dan bidangnya masing-masing. Hal ini sudah sesuai dengan Peraturan Pemerintah No. 61 tahun 2010, Pasal 12 menjelaskan bahwa Pejabat yang dapat ditunjuk sebagai PPID di lingkungan Badan Publik Negara yang berada di pusat dan di daerah merupakan pejabat yang membidani informasi publik. Dalam hal ini, pejabat ini ditunjuk oleh pimpinan disetiap badan publik. Mereka yang menjabat sebagai PPID memiliki kompetensi di bidang pengelolaan informasi dan dokumentasi. Akan tetapi, dengan adanya hal tersebut, maka kurang maksimalnya tugas dan kewajiban PPID dalam melayani masyarakat. Berdasarkan observasi, peneliti beberapa kali datang ke Kantor PPID, namun sering kali para pejabat PPID Tuban tidak berada di tempat. Sehingga perlu adanya suatu solusi yang dilakukan oleh pihak Pemerintah Daerah supaya kinerja dari PPID Tuban itu bisa maksimal.

Kemudian dalam hal pengoordinasian PPID sendiri dilaksanakan pada tahun 2009 dan kemudian disahkan pada 2010. Mengingat bahwa dalam UU Nomor 14 Tahun 2008 
tentang Keterbukaan Informasi Publik, maka harus dibentuk maksimal pada tahun 2010. Seiringnya waktu, PPIDTuban diganti pada tahun 2012 yang disahkan dengan Surat Keputusan Bupati Tuban Nomor 188.45/122/KPTS/414.012/2012 tentang Pejabat Pengelola Informasi dan Dokumentasi Kabupaten Tuban.

Pengoordinasian internal PPID Tuban ini dilaksanakan 3 (Tiga) bulan sekali melalui rapat-rapat koordinasi yang melibatkan atasan PPID yaitu kepala Dinas Komunikasi dan Informatika (Diskominfo). Hal ini dikarenaka tidak memungkinkan ketika dilaksanakan satu bulan sekali, karena pejabat PPID Tuban ini juga merangkap OPD lain di Pemerintah Daerah. Sehingga dalam analisis peneliti, tugas PPID sendiri kurang maksimal karena dalam pengoordinasiannya hanya dilakukan dalam tiga bulan sekali. Hal ini akan mempersulit PPID sendiri ketika PPID mempunyai masalah yang harus diselesaikan. Sehingga sebagai sinergitas dalam temuan peneliti, maka pelu adanya suatu reformasi yang terjadi di internal PPID dengan dibentuknya pejabat yang benar-benar fokus pada internal PPID dan bukan merangkap dengan OPD yang lain.

Kemudian dalam sistem pengkomunikasian para pejabat internal PPID maupun dalam melaksanakan pelayanan keterbukaan informasi publik, PPID Tuban dibantu oleh staf pelayanan yang bertugas menerima dan melayani pengunjung di kantor PPID Kabupaten Tuban. Namun dalam hal ini, staf pelayanan tidak mempunyai wewenang apapun untuk memutuskan permasalahan yang dihadapi oleh PPID dalam bidang pelayanan keterbukaan infromasi publik. Kecuali menyampaiakan informasi yang sudah diputuskan oleh Ketua PPID yang diminta oleh pemohon.

Sebelum melaksanakan tugasnya, staf sudah diberikan pembekalan atau breafing yang disesuaikan dengan alur pelayanan atau SOP yang sudah ditetapkan oleh PPID Tuban. Sehingga dalam analisis ini, dalam pengkomunikasiaan PPID sudah baik dan berdasarkan data observasi, dalam pelayanannya, PPID Tuban sudah sesuai dengan alur pelayanan atau SOP yang sudah ditetapkan. 
Standart Operasional Prosedural (SOP) dalam pelayanan juga sudah sangat bagus dan simpel. Seperti gambar di bawah ini:
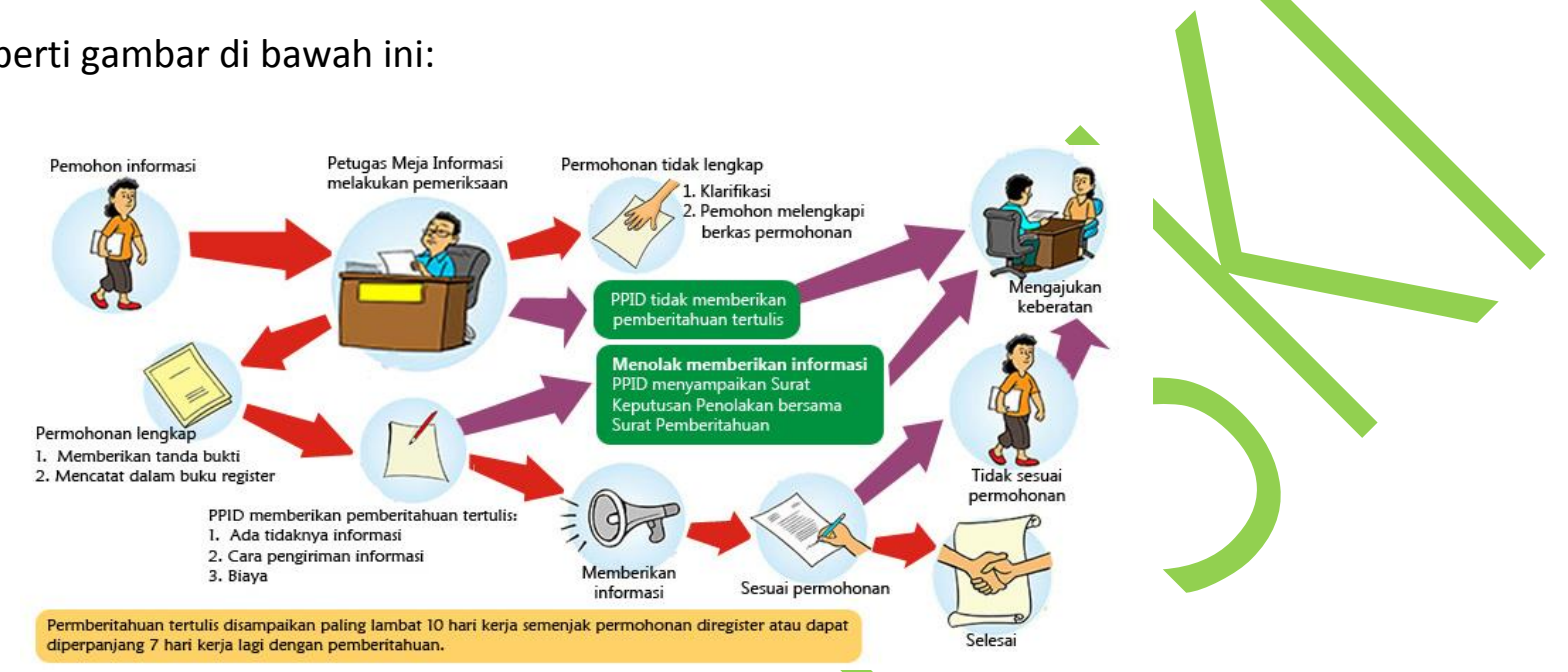

Gambar 2. Alur Pelayanan Permohonan Informasi

Sumber: Dokumen PPID Tuban

Pada gambar di atas, bisa kita lihat bahwa alur pelayanan PPID Tuban sudah sangat simple dan efisian. Seorang pemohon hanya melewati dua tahap saja, yaitu dengan membawa berkas permohonan lengkap ke petugas pelayanan informasi dan menunggu sampai adanya pemberitahuan dari PPID Tuban, maka seorang pemohon sudah bisa mendapatkan informasi yang diinginkan. Dengan catatan bahwa informasi tersebut ada di Dokumen PPID Tuban. Selain itu juga tentunya sudah sesuai dengan Peraturan Bupati Tuban Nomor 59 Tahun 2015 tentang Penetapan Standar Operasional Prosedur Pelayanan Informasi Publik Pejabat Pengelola Informasi dan Dokumentasi di Lingkungan Pemerintah Kabupaten Tuban.

Selain SOP dalam pelayanan, PPID Tuban juga mempunyai SOP pelayanan keberatan bagi pemohon yang kurang puas dengan pelayanan PPID Tuban. Alur keberatan ini juga diatur dalam Peraturan Bupati Tuban Nomor 59 Tahun 2015 tentang Penetapan Standar Operasional Prosedur Pelayanan Informasi Publik Pejabat Pengelola Informasi dan Dokumentasi di Lingkungan Pemerintah Kabupaten Tuban. Adapun gambar alur keberatan sebagai berikut: 


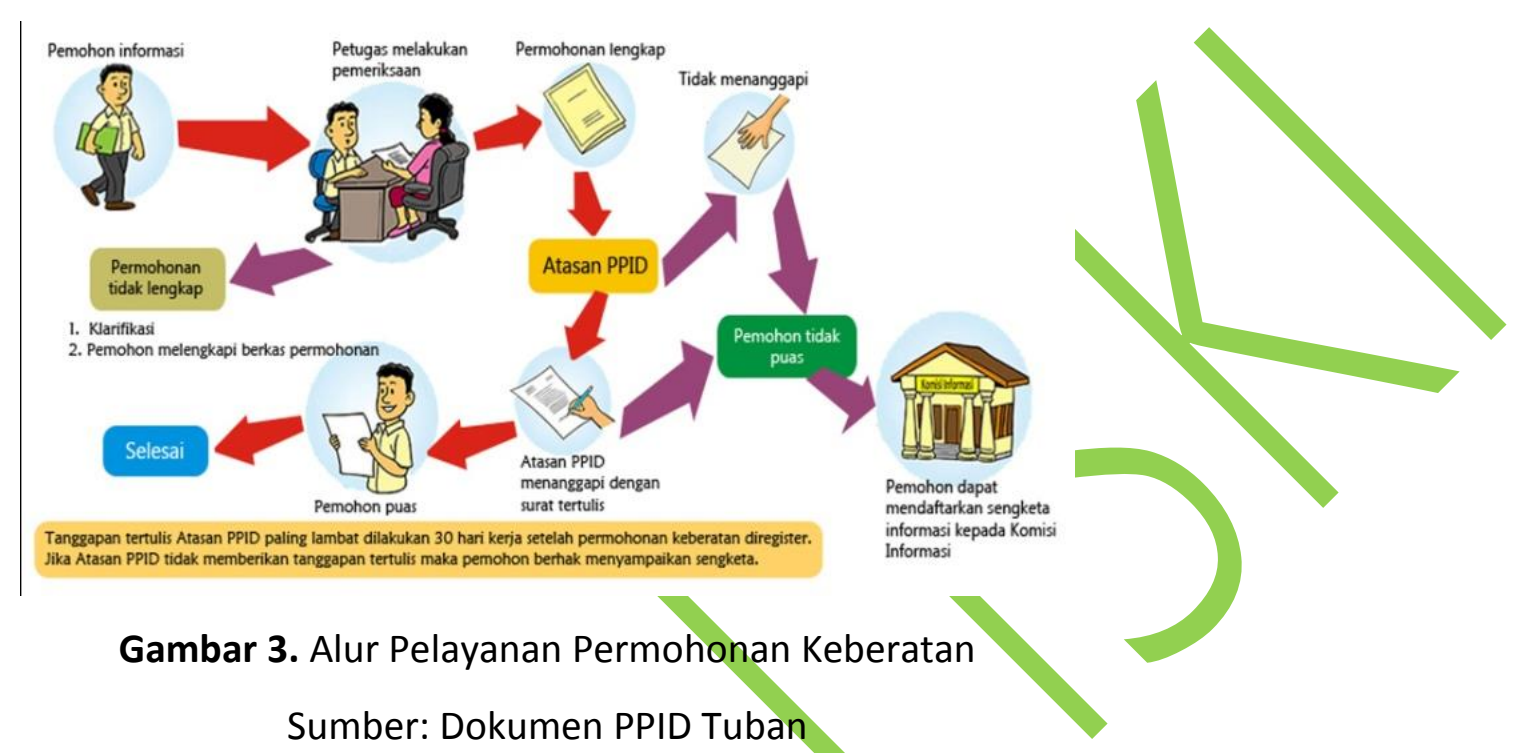

Pada gambar 2 bisa kita lihat bahwa, pelayanan permohonan keberatan yang disediakan oleh PPID Tuban juga cukup melewati 2 (Dua) tahap saja, yaitu dengan memberikan berkas pemohonan lengkap dan menunggu tanggapan dari atasan PPID Tuban. Akan tetapi, dalam permohonan tersebut hanya di layani maksimal 14 hari jam kerja setelah mendapatkan informasi. Jika lebih dari 14 hari jam kerja tidak akan dilayani ataupun ditanggapi dengan alasan kadaluarsa. Hal ini sesuai dengan UU No. 14 Tahun 2008 Pasal 37 bahwa Upaya Penyelesaian Sengketa Informasi diajukan masyarakat Kepada Komisi Informasi Pusat dan/atau Komisi Informasi Provinsi dan/atau Komisi Informasi Kabupaten/Kota Sesuai dengan kewenangannya apabila tanggapan atasan Pejabat Pengelola Informasi dan Dokumentasi dalam Proses keberatan tidak memuaskan Pemohon Informasi Publik dan Upaya Penyelesaian Sengketa Informasi Publik diajukan dalam waktu paling lambat 14 (empat belas) hari kerja setelah diterimanya tanggapan tertulis dari atasan pejabat sebagaimana dimaksud dalam Pasal 36 ayat (2).

Pelaksanaan pelayanan keterbukaan informasi publik, PPID Tuban hanya baru bisa melayani di tempat. Dalam hal ini maksudnya adalah proses pelayanan keterbukaan informasi publik tersebut hanya bisa terjadi ketika pemohon datang di kantor PPID Tuban. Sehingga perlu adanya suatu terobosan untuk mengantisipasi masyarakat yang berada di 
daerah Pinggiran Kabupaten Tuban. Seperti adanya pelayanan secara online melalui wabsite resmi PPID Tuban. Sehingga masyarakat di daerah pinggiran yang jauh dari Kota tersebut bisa lebih mudah untuk melakukan permohonan memalui online dan tentunya masyarakat tidak malas untuk meminta informasi di PPID karena pelayanannya sudah mudah dan tentunya harus simple. Sehingga bisa meningkatkan minat masyarakat untuk meminta informasi di Kabupaten Tuban.

PPID Tuban hanya melayani dokumen yang diminta oleh Organisasi berbadan hukum dan tidak perorangan. Kemudian dalam hal memutuskan dokumen yang akan diberikan kepada pemohon, PPID Tuban selalu diputuskan melalui koordinasi internal PPID Tuban. Karena melalui pertimbangan bahwa PPID Tuban ini juga sebuah Tim. Berdasarkan hal tersebut, secara pelaksanaannya PPID Tuban memang sudah sesuai prosedural.

Kemudian untuk pengawasan PPID Tuban, yang berhak untuk mengawasi adalah Kepala Dinas Komunikasi dan Informatika (Diskominfo) selaku atasan PPID Kabupaten Tuban. Selain itu, ada juga Komisi Informasi Publik Jawa Timur yang memang bertugas mengawasi jalannya keterbukaan informasi publik di Jawa Timur. Langkah dalam mengawasinnya melalui kunjungan ke kantor PPID Tuban. Bidang yang diawasipun tidak hanya pelayanan, melainkan kepuasan pemohon yang dalam hal ini adalah Dokumen yang dimohon apakah sudah sesuai dengan yang diinginkan oleh pemohon atau tidak. Sehingga pengawas PPID juga mempunyai acuan tersendiri untuk menilai kinerja dari pada PPID Tuban. Akan tetapi, PPID tidak mempunyai acuan untuk mengukur dirinya sendiri. Dalam hal ini, PPID Tuban tidak mempunyai penilaian bagi internalnya sendiri. Sehingga sebagai rekomendasi dari penelitian ini, mkaka perlu adanya suatu instrumen kinerja Pejabat PPID Tuban untuk mengukur kinerja dan menjadi pelayan yang baik bagi masyarakat Tuban.

Kemudian dalam bidang pelaksanaan Pengevaluasian, PPID Tuban melakukan rapat 3 (Tiga) bulan sekali yang melibatkan atasan PPID selaku orang yang berhak untuk mengevaluasi kinerja PPID Tuban yaitu Kepala Dinas Komunikasi dan Informatika (Diskominfo). Hal ini bisa menghambat kinerja dari PPID sendiri, karena dalam pelaksanaan 
pelayanan idealnya dilakukan selama 1 (Satu) bulan sekali untuk mengetahui hambatanhambatan yang sudah dihadapi oleh PPID Tuban. Selama ini, PPID Tuban berdasarkan data yang diperoleh hampir tidak ada kendala dalam pelaksanaan pelayanan, tapi pernah mengalami kesulitan dalam melaksanaan pelayanan kepada pemohon yang meminta data pada masa Orde Lama. Sehingga PPID tidak bisa memenuhi permohonan tersebut. Sehingga dalam hal ini, PPID Tuban masih belum maksimal dalam pelayanannya, karena masih belum bisa memenuhi dokumen yang diminta oleh Pemohon yang mestinya dokumen itu merupakan dokumen yang harus di simpan.

Selain itu, sebagai bentuk suatu evaluasi, PPID Tuban mestinya mempunyai alat untuk mengukur tingkat kepuasan pelayanan keterbukaan informasi publik. Namun kondisi yang ditemukan peneliti tidak survai ataupun angket untuk mengukur tingkat kepuasan pelayanan keterbukaan informasi. Sehingga sebagai bentuk evaluasi, maka PPID Tuban harus membuat terobosan supaya mengetahui tingkat kepuasan pelayanan keterbukaan informasi publik. Supaya tidak terjadi sengketa yang sudah dialami oleh PPID Tuban, bahwa PPID Tuban pernah mengalami sengketa dua kali dengan LSM yang berada di Kabupaten Tuban. Meskipun tim penilai atau hakim informasi memutuskan yang benar adalah PPID Tuban, alangkah lebih baiknya PPID Tuban mengantisipasi supaya tidak terjadi kembali.

Kemudian dalam hal antusias masyarakat kepada PPID, sudah dilaksanakan sosialisasi di desa-desa yang dilakukan oleh PPID sediri. Namun pada dasarnya masih sangat minim. Sehingga perlu adanya sosialisasi yang dilakukan oleh PPID melalui cara lain, seperti pemasangan Baliho di Desa-desa, Iklan di media ataupun yang lainnya. Supaya antusias masyarakat juga bisa meningkat. Kemudian jika kita mengetahui bahwa budaya masyarakat Tuban masih senang mendengarkan daripada membaca, maka iklan melalui media sosial atau televisi menjadi solusi untuk bisa meningkatkan partisipasi masyarakat Tuban kepada PPID Tuban.

Setelah Evaluasi yang dilakukan oleh Ketua Dinas Komunikasi dan Informatika (Diskominfo) dan Komisi Informasi Publik, maka hasil evaluasi itu akan diberikan kepada 
PPID Tuban untuk ditindak lanjuti sebagai bentuk pemodifikasian dan sebagai acuan untuk melaksanakan tugas dari pada PPID Tuban Ke depannya. Adapun pemodifikasian yang dilakukan sesuai dengan hasil evaluasi. Seperti halnya pemodifikasian yang dilakukan pada Tahun 2012 tentang format pergantian struktur PPID.

PPID Tuban dalam pelaksanaan pelayanan berdasarkan uraian di atas, maka pelaksanaan pelayanan yang dimulai dari perencanaan sudah sangat bagus sekali, karena dalam perencanaan pelayanan ini PPID Tuban sudah mempunyai Standart Operasional Prosedural (SOP) sebagai langkah dalam pelayanan yang disusun berdasarkan peraturan Bupati Nomor 59 Tahun 2015. Di dalam peraturan itu juga tertuang batas waktu maksimal PPID Tuban dalam melaksanakan pelayanan keterbukaan informasi publik. Kemudian dalam hal pengoorganisasian Sumber Daya Manusia (SDM) yang ditunjuk langsung oleh Bupati dengan melibatkan Organisasi Perangkat Daerah (OPD) disesuaikan dengan kualitas dan bidang masing-masing. Namun, dengan adanya rangkap jabatan ini, membuat pelayanan tidak maksimal karena fokus kinerja juga terpecah dengan tugas yang lain. Sehingga ini mempengaruhi koordinasi yang ada di dalam internal PPID. Koordinasi yang dilakukan selama tiga bulan sekali ini tidak efektif karena bisa membuat kendala dalam organisasi. Sehingga dalam komunikasi kepada stafpun juga akan terhambat karena kurangnya koordinasi mengenai pelayanan keterbukaan informasi publik di PPID Tuban. Staf PPID sendiri memang sudah diberikan arahan dalam melaksanakan tugasnya. Namun, staf pelayanan PPID tidak mempunyai wewenang apapun untuk memutuskan suatu hal yang sekiranya penting dan harus menunggu memo dari atasan.

Adanya koordinasi yang kurang maksimal, membuat komunikasi di internal PPID juga terhambat dan ini akan berakibat pada pelaksanaan pelayanan keterbukaan informasi publik. Dalam pelaksanaannya PPID Tuban baru bisa melakukan pelayanan di tempat dan belum bisa melakukan pelayanan e-service dalam keterbukaan infromasi publik. Sehingga ini bisa mengakibatkan minimnya masyarakat dalam menggunakan haknya dikarenakan 
jarak tempuh yang jauh. Dengan adanya pelaksanaan yang kurang maksimal ini, bisa berimbas dari penilaian pengawasan oleh Komisi Informasi Publik Jawa Timur.

Kemudian disamping dalam pelaksanaan pelayanan informasi publik yang kurang maksimal itu, PPID Tuban dalam pelaksanaan evaluasi juga hanya melibatkan Atasan dan pejabat PPID Tuban sendiri. PPID Pembantu yang ada di Kecamatan ataupun Dinas tidak dilibatkan dalam pelaksanaan evaluasi, sehingga ini akan mengakibatkan kurangnya koordinasi dan minimnya suatu kesalahan yang di ketahui oleh para PPID Pembantu. Dengan minimnya pengetahuan akan kesalahan dalam pelaksanaan pelayanan PPID Pembantu, maka akan berakibat kurang maksimalnya dalam pelayanan keterbukaan informasi publik. Sehingga dengan adanya penerapan modifikasi yang didasarkan pada evaluasi tersebut bisa meningkatkan kinerja PPID Tuban dalam pelaksanaan pelayanan.

Kemudian untuk teori sistem sosial dalam manajemen komunikasi PPID Kabupaten Tuban dalam pelaksanaan pelayanan keterbukaan informasi publik, berdasarkan konsep dari teori sistem bahwa PPID Kabupaten Tuban termasuk pola organisasi open system. Hal ini dikarenakan bahwa organisasi PPID Tuban ini mempunyai transaksi dimana dia berdara. Maksudnya PPID Tuban ini mempunyai transakssi dalam bidang informasi dan dokumentasi dengan masyarakat yang ada di Kabupaten Tuban. Sehingga ini menjadi klasifikasi bahwa PPID Tuban merupakan organisasi yang menggunakan Pola Open System.

Menurut Owens bahwa teori sistem memiliki dua konsep dasar yaitu yang pertama adalah konsep subsistem yang melihat hubungan antar bagian sebagai hubungan sebab akibat. Dalam hal ini, PPID Kabupaten Tuban juga mempunyai Subsistem yang ada di setiap instansi-instansi seperti dinas-dinas dan juga kecamatan-kecamatan yang disebut sebagai Pejabat Pengelola Informasi dan Dokumentasi Pembantu (PPIDP). Namun, dalam pelaksanaannya tidak bisa maksimal, hal ini disebabkan karena kurang antusiasnya para pelaku pejabat PPID Pembantu yang ada di setiap instansi. Sehingga membuat kurang antusiasnya masyarakat untuk menggunakan Haknya memohon informasi publik. 
Konsep kedua memandang sebab jamak (multiple causation) sebagai hubungan yang saling berkaitan yakni tiap bagian merupakan kompleks (kumpulan) yang tiap faktornya saling berkaitan. Sebagai suatu organisasi, PPID Tuban juga mempunyai struktur yang saling berkaitan. Seperti contoh antara bisang pelayanan dan bidang penyedia informasi yang berkaitan dalam hal pelayanan keterbukaan informasi. Tidak hanya pada internal saja, melainkan PPID juga mempunyai hubungan dengan masyarakat selaku pemohon informasi. Dalam hal ini, PPID menjadi organisasi penyedia informasi atau produsen informasi dan masyarakat menjadi konsumen informasi. Namun, dalam pelaksanaan pelayanan PPID Tuban kepada masyarakat yang merupakan suatu bagian dari sistem sosial, masih ada hal yang membuat masyarakat tidak bisa puas dengan adanya pelayanan di interrnal PPID Tuban. Hal Ini bisa dibuktikan bahwa PPID Tuban sudah pernah digugat ataupun dipermaslaahkan sebanyak kali oleh masyarakat dalam hal pelayanannya.

\section{KESIMPULAN}

Manajemen Komunikasi merupakan proses penggunaan berbagai sumber daya komunikasi secara terpadu melalui proses perencanaan, pengorganisasian, pelaksanaan, dan pengontrolan unsur-unsur komunikasi untuk mencapai tujuan yang telah ditetapkan. Manajemen komunikasi yang meliputi penelitian, perencanaan, pelaksanaan dan evaluasi ini sering kali tidak disadari bahwa manajemen komunikasi selalu diterapkan di dalam lembaga swasta ataupun pemerintah.

Berdasarkan peneltian yang sudah dilakukan dengan metode audit komunikasi, maka pada dasarnya Pejabat Pengelola Informasi dan Dokumentasi Kabupaten Tuban sudah melaksanakan manajemen komunikasi. Namun, dalam segala penerapannya PPID Kabupaten Tuban masih belum maksimal. Hal ini dikarenakan faktor-faktor dari internal maupun eksternal. Manajemen komunikasi PPID dalam perencanaannya memang sudah sangat bagus dan sudah mempunyai dasar dalam penentuan setiap kebijakan perencanaan.

Bahkan pengorganisasiannya juga sudah bagus dengan penempatan SDM yang sesuai 
bidangnya. Namun dalam pengoordinasian dan pengkomunikasian suatu perencaan masih lemah, sehingga membuat pelaksanaan pelayanan keterbukaan infromasi publik kurang maksimal, sehingga membuat pengawasan PPID semakin mendapat nilai jelek dan hasil evaluasi yang banyak tanpa disertai modifikasi.

Manajemen komunikasinya dalam internal PPID Kabupaten Tuban dalam pelaksanaan teori sistem, PPID Kabupaten Tuban sudah sesuai dengan teori ini, dimana dalam struktural PPID Tuban sudah mempunyai tugas dan wewenang masing-masing yang saling berkaitan antara satu dengan yang lainnya. Namun masih ada kendala dalam sinkronisasi dengan PPID Pembantu yang ada di setiap Dinas atau kecamatan di kabupaten Tuban. 


\section{DAFTAR PUSTAKA}

Abidin, Yusuf Zainal, Manajemen Komunikasi: Filosofi, Konsep dan Aplikasi: Pustaka Setia:Bandung: 2015

Dunn, William N. 2003. Analisis Kebijakan Publik. Yogyakarta : Gadjah Mada University Press.

Hardjana, Andre. 2000. Audit Komunikasi: Teori dan Praktek. PT. Grasindo. Jakarta.

Hutasoit, C.S. (2011).Pelayanan Publik:Teori dan Aplikasi.Jakarta:MagnaScript Publishing.

Liliweri, Alo: Komunkasi Serba Ada Serba Makna: Kencana: 2011

Mukarom, Zainal dan Muhibudin Wijaya Laksana, Manajemen Public Relation: Pustaka Setia:Bandung: 2015

Moenir, H.A.S. (2006). Manajemen Pelayanan Umum di Indonesia. Bumi Aksara. Jakarta.

Sugiono,Metode Penelitian Kuantitatif, KualitatifDanR\&D:Alfabeta.Cv: Bandung: 2014.

Munawar, Soiana, 2012. Keterbukaan Informasi Publik Dalam Persepektif Governability. http://politik.Kompasiana.com/2012/01/28/keterbukaan-informasi-publikdalam-persepektif-governability/diakses tanggal 31 Desember 2016: 18.32 WIB

Ngurah Putra, I Gusti. 1998. Manajemen Hubungan Masyarakat. Universitas Atmajaya. Yogyakarta

Peraturan Pemerintah Nomor 96 Tahun 2012 Tentang Pelaksanaan Undang-undang Nomor 25 Tahun 2009 Tentang Pelayanan Publik (LembaranNegara RepublikIndonesiaTahun2012Nomor 215, TambahanLembaran Negara Republik Indonesia Nomor 5357);

Peraturan Presiden Nomor 97 Tahun 2014 tentang Penyelenggaraan Pelayanan Terpadu Satu Pintu;

Ruslan, Rosady. 2005. Manajemen Public Relations dan Media Komunikasi. Jakarta: PT Raja Grafindo Persada.

Suprapto,Tommy. 2005. Pengantar Teori \& Manajemen Komunikasi. Yogyakarta: MedPress

Undang-Undang Nomor 14 Tahun 2008 tentang Keterbukaan Informasi Publik 
Undang-Undang Nomor 25 Tahun 2009 tentang Pelayanan Publik (Lembaran Negara Republik Indonesia Tahun 2009 Nomor 112, Tambahan Lembaran Negará Republik Indonesia Nomor 5038);

Indarto, Marroli J., Tesis Menejemen Komunikasi Pemerintah dalam Kebijakan Transparansi Informasi (Studi Evaluasi Keterbukaan Informasi Publik Pada Kementrian Informasi dan Komunikasi), Universitas Indonesia, 2012. 